\title{
Casing Mixture for Improved Growth and Yield of Mushroom Variety Makandura White (Calocybe sp.)
}

\author{
E.M.R.A. Edirisinghe ${ }^{1}$, P. Rajapakshe ${ }^{2}$ and R.H.M.K. Ratnayake ${ }^{1, *}$
}

\begin{abstract}
Makandura White (MK-White; Calocybe sp.) is a newly introduced edible mushroom variety. Cultivation of MK-White requires a specific agronomic practice called 'casing'. Currently, the only casing material used in Sri Lanka is composed of termite clay soil, sand and dry cattle manure in 3:1:1 proportion. Due to limited availability of termite clay soil, the present study was undertaken to find out an alternative casing mixture which can be developed using readily available local material. Six different casing mixtures were used against a control without a casing (Control 1). Casing mixtures of termite clay soil: sand: dry cattle manure (3:1:1; Control 2), half burnt paddy husk: dry cattle manure (2:1) and dry cattle manure: sand: loamy soil (1:1:1) took less number of days (4.1 days) to appear mycelium on casing. Pin head formation was fastest in the casing mixture of half burnt paddy husk: dry cattle manure $(2: 1 ; 32.3$ days) and in the mixture containing dry
\end{abstract}

${ }^{1}$ Department of Horticulture and Landscape Gardening, Faculty of Agriculture and Plantation Management, Wayamba University of Sri Lanka, Makandura, Gonawila (NWP)

${ }^{2}$ Regional Agriculture Research and Development Centre, Makandura, Gonawila (NWP), 60170, Sri Lanka

*kamani.ratnayake@uqconnect.edu.au http://orcid.org/0000-0002-4055-5372

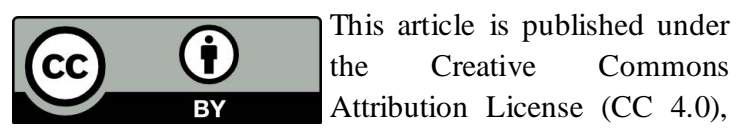

which permits unrestricted use, distribution, and reproduction in any medium, provided the original work is properly cited. cattle manure: sand: loamy soil $(1: 1: 1 ; 36.6$ days). Highest yield per bag within 21 days of pin head formation was obtained from the casing mixtures of termite clay soil: sand: dry cattle manure $(3: 1: 1 ; 84.63 \mathrm{~g})$ and half burnt paddy husk: dry cattle manure (2:1; $82.05 \mathrm{~g}$ ). The casing mixture of half burnt paddy husk: dry cattle manure (2:1) provided the required physico-chemical conditions to grow MK-White mushroom. Therefore, termite clay soil, sand and dry cattle manure mixture can be replaced with the readily available half burnt paddy husk, dry cattle manure (2:1) mixture for MKWhite mushroom cultivation.

Keywords: Calocybe sp., Casing, Makandura White, Mushroom, Yield

\section{INTRODUCTION}

Edible mushrooms are an excellent source of protein, minerals and vitamins. Although more than 2000 species of edible mushrooms exist in nature, approximately 22 species are intensively cultivated for commercial purposes (Colak et al., 2007). The most widely grown mushroom in Sri Lanka is oyster mushroom (Pleurotus sp.; Anon, 2016a). Introduction of new varieties is essential to popularize production and consumption of mushroom in Sri Lanka.

The Department of Agriculture (DOA), Sri Lanka has introduced a new edible mushroom variety called "Makandura White" (MK-White; Calocybe sp.) which was released to public in 2015. MK-White 
possesses special characteristics such as consistent yield, attractive colour, deliciousness, unique texture, extended shelf life and less susceptibility to pest attacks. As a newly introduced variety, MKWhite is gaining increased popularity among mushroom growers in Sri Lanka (Anon., 2016b).

However, the commercial production of MK-White mushroom in Sri Lanka is still in the developing stage due to limited availability of mushroom spawn (seeds) and lack of knowledge on production technology. MK-White requires a temperature of $28^{\circ} \mathrm{C}-32^{\circ} \mathrm{C}$ and a relative humidity (RH) of $85 \%-90 \%$ for better, early mycelium growth and fruiting body formation. Therefore, it can be successfully grown in areas with high temperature and high RH. Unlike in oyster mushroom, MKWhite mushroom cultivation has an additional agronomic practice called 'casing'. Compost (growing medium) and casing mixture are the two major substrates that affect yield in commercial production of MK-White. A softwood saw dust such as rubber, is the preferred growing medium at commercial scale. However, after the completion of spawn run, the compost should be covered with a thin casing layer to initiate the development of sporophores. Casing helps trigger off the change from vegetative to reproductive phase (Subbiah and Balan, 2015). Casing layer, which is a nutritionally deficient medium, stimulates mushroom formation by giving a stress condition to the mycelium. In addition, casing layer helps keep moisture inside the grow bags and acts as a barrier for contamination.

Although peat soil is the most common and recommended casing used in mushroom culture (Baysal et al., 2007), importation of peat involves high cost in the Sri Lankan context. At present, a mixture of termite clay soil, sand and dry cattle manure ( $3: 1: 1 \mathrm{w} / \mathrm{w})$ is used as the casing material for MK-White mushroom production. No attempt has been taken to introduce alternative casing materials while difficulties exist in supplying termite clay soil in large volumes. Therefore, the objective of this study was to identify locally available cost effective and high yielding casing materials for the cultivation of MK-White mushroom and, thereby, enhance and popularize MK-White mushroom production among Sri Lankan growers.

\section{MATERIALS AND METHODS Experimental Site}

The study was carried out at the Regional Agriculture Research and Development Centre (RARDC), Makandura, Sri Lanka situated in the Low country Intermediate Zone (IL $\mathrm{I}_{\mathrm{a}} ; 25 \mathrm{~m}$ above $\mathrm{msl}$ ) from May to September 2017. During the period, the maximum and minimum temperatures and the average $\mathrm{RH}$ in the experimental site were $33{ }^{\circ} \mathrm{C}, 24{ }^{\circ} \mathrm{C}$ and $80 \%$, respectively.

\section{Preparation of Growing Medium}

The required quantity of growing medium 
was prepared using raw materials as $100 \mathrm{~kg}$ saw dust of rubber, $10 \mathrm{~kg}$ of rice polish, $2.5 \mathrm{~kg}$ of dolomite, $1 \mathrm{~kg}$ of gypsum and 250 $\mathrm{g}$ of $\mathrm{MgSO}_{4}$. The ingredients were mixed thoroughly while adding water till the moisture content was adjusted to $55-60 \%$ (on wet weight basis). Polypropylene bags (200 gauge; length $25 \mathrm{~cm}$, width $17.5 \mathrm{~cm}$ ) were filled with the growing medium, $1.2 \mathrm{~kg}$ per bag. Each bag was sealed with a cotton plug using a polyvinyl chloride (PVC) pipe ring and covered with a piece of paper by tying a rubber band around the neck. The grow bags were sterilized using a boiler at $110{ }^{\circ} \mathrm{C}$ and $1.5 \times 10^{5} \mathrm{~Pa}$ for $1.5 \mathrm{~h}$. Sterilized bags were allowed to cool to room temperature for $24 \mathrm{~h}$.

Spawn of MK-White was obtained from RARDC, Makandura. Under aseptic conditions, the grow bags were inoculated with mycelial culture of MK-White and incubated in the dark. The average maximum and minimum temperatures and $\mathrm{RH}$ inside the incubation room were recorded as $32{ }^{\circ} \mathrm{C}, 24{ }^{\circ} \mathrm{C}$ and $80 \%$, respectively. Spawn run period completed within $25-30$ days.

\section{Preparation and Application of Casing Layer}

Casing mixtures were prepared using termite clay soil, sand, dry cattle manure, paddy soil, coir dust, half burnt paddy husk, compost and loamy soil (Table 1). Coir dust and paddy husk were bought from the local market while other casing materials were prepared at RARDC, Makandura. Raw materials were mixed together while adding water. Casing mixtures were tested for $\mathrm{pH}$ before sterilization to ensure the value was between $7.2-7.5$. Casing materials were sterilized at $110{ }^{\circ} \mathrm{C}$ and $1.5 \times 10^{5} \mathrm{~Pa}$ for $1.5 \mathrm{~h}$ and allowed to cool to room temperature for $24 \mathrm{~h}$. After mycelium colonization, top of the mushroom compost medium was covered with a layer of casing mixture to a thickness of $1-2 \mathrm{~cm}$. Mouth of the bags were closed by tying a rubber band and the bags were transferred to the mushroom grow house to facilitate formation of fruiting bodies. During the reproduction period the average maximum and minimum temperatures and $\mathrm{RH}$ in mushroom grow house were $32{ }^{\circ} \mathrm{C}, 24{ }^{\circ} \mathrm{C}$ and $80 \%$, respectively.

\section{Physicochemical Properties of Casing Materials}

Prepared casing mixtures were checked for their bulk density, porosity, $\mathrm{pH}$ and moisture content (Table 1). Bulk density was determined by measuring the weight of casing mixture filled into a $212 \mathrm{~cm}^{3}$ cylinder and was calculated using mass of solid fraction and volume of casing material (Rainey, 1985). The percentage total porosity in casing mixtures was calculated after determining the particle and bulk densities (Rainey, 1985). pH of the prepared stirred suspensions was measured using a pH meter (HI 98129, Hanna instruments, USA) by following water solution method (Rainey, 1985). Moisture content on dry weight basis was determined by oven drying the casing mixtures at $105{ }^{\circ} \mathrm{C}$ for $24 \mathrm{~h}$ or to a constant weight. 


\section{Data Recording}

Data on the number of days taken to appear mycelium on casing mixture, days taken for first pin head formation, first harvest and the yield per bag within 21 days of pin head formation were recorded. The total yield per bag was computed for a period of 2 months.

\section{Experimental Design and Data Analysis}

The experiment was arranged in a Completely Randomized Design (CRD) with three replicates. Six casing mixtures were used as treatments and each replicate consisted of five mushroom grow bags. Data were analyzed by Analysis of Variance (ANOVA) and the means were compared using Least Significant Difference (LSD) test using Statistical Analysis System (SAS) Ver. 9.4.

\section{RESULTS AND DISCUSSION Effect of Casing Mixture on Mycelium Growth, Pin Head Formation and Yield}

Casing mixtures of termite clay soil: sand: dry cattle manure (3:1:1; Control 2$)$, half burnt paddy husks: dry cattle manure $(2: 1)$ and dry cattle manure: sand: loamy soil $(1: 1: 1)$ took significantly less number of days (4.1 days) to appear mycelium on casing as compared to other mixtures (Table 2 ). The longest time of 6.1 days was taken by the mixture containing coir dust; compost; dry cattle manure (1:1:1).

Pin head formation was fastest $(32.3$ days) in the casing mixture of half burnt paddy husk: dry cattle manure $(2: 1)$ followed by the mixture containing dry cattle manure: sand: loamy soil $(1: 1: 1 ; 35.7$ days; Table 2). Out of the five casing mixtures, longest time for pin head formation was recorded by the mixtures of coir dust: compost: dry cattle manure (1:1:1) and paddy soil: coir dust (1:1.5) which were 41.4 days and 40.9 days, respectively. Pin heads were formed in the absence of a casing although it took 46 days. Moreover, it appears that the two casing mixtures containing coir dust needed more time for mycelium growth and pin head formation (Table 2).

Generally, mushrooms are harvested based on maturity than on size. MK-White was harvested at its button stage before the gills rupture as delayed harvesting causes mushroom cap to fully open and gradually turn yellow (Figure 1). Number of days taken for the first harvest in the casing mixture of half burnt paddy husk: dry cattle manure (2:1) was the lowest (40.0 days) and it was significantly different from all other mixtures (Table 2). Maximum yield per bag $(84.63 \mathrm{~g})$ within 21 days of pin head formation was obtained from the casing mixture of termite clay soil: sand: dry cattle manure (3:1:1). However, it was statistically similar to the yield $(82.05 \mathrm{~g})$ given by the mixture of half burnt paddy husk: dry cattle manure (2:1). Lowest yield per bag $(49.23 \mathrm{~g})$ was recorded in the absence of a casing (Table 2).

Jayanga et al. (2016) investigated the effect of different casing mixtures on yield of button mushroom (Agaricus bisporus) where the second highest yield per bag 

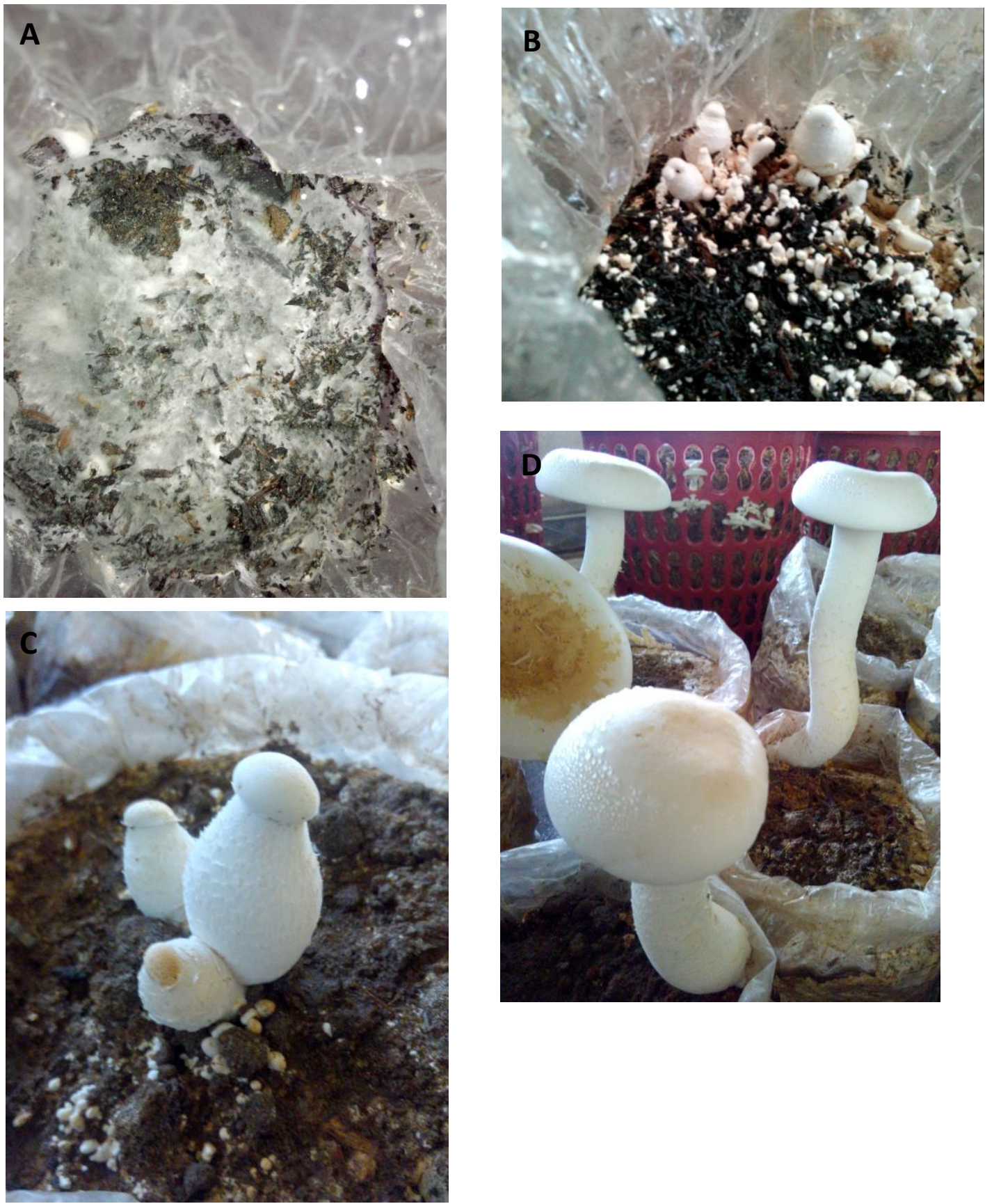

Figure 1. Growth stages of Makandura White mushroom on the casing mixture of half burnt paddy husk and dry cattle manure (2:1). (A) Growth of mycelium on casing (B) Pin head formation (C) Early stages of growth (D) Mushroom at first harvest. 
Table 1. Casing mixtures used for mushroom variety Makandura White and their physicochemical properties

\begin{tabular}{lcccc}
\hline Casing mixture & $\begin{array}{c}\text { Bulk } \\
\text { density } \\
\left(\mathbf{g} / \mathbf{c m}^{\mathbf{3}}\right)\end{array}$ & $\begin{array}{c}\text { Porosity } \\
(\boldsymbol{\%})\end{array}$ & $\mathbf{p H}$ & $\begin{array}{c}\text { Moisture } \\
\text { content* } \\
(\boldsymbol{\%})\end{array}$ \\
\hline No casing - Control 1 & - & - & - & - \\
Termite clay soil : Sand: DCM (3:1:1)-Control 2 & 0.75 & 79 & 7.23 & 61.02 \\
Paddy soil : Coir dust (1:1.5) & 0.78 & 61 & 7.25 & 45.91 \\
Half burnt paddy husk : DCM (2:1) & 0.35 & 86 & 7.30 & 63.65 \\
Coir dust: Compost: DCM (1:1:1) & 0.37 & 92 & 7.35 & 72.96 \\
DCM : Sand : Loamy soil (1:1:1) & 0.80 & 47 & 7.42 & 12.32 \\
\hline
\end{tabular}

${ }^{*}$ Dry weight basis. DCM-Dry cattle manure

Table 2. Effect of casing mixtures on mycelium growth, pin head formation and yield of mushroom variety Makandura White

\begin{tabular}{lcccc}
\hline Casing mixture & $\begin{array}{c}\text { Days to } \\
\text { appear } \\
\text { mycelium } \\
\text { on casing }\end{array}$ & $\begin{array}{c}\text { Days to first } \\
\text { pin head } \\
\text { formation }\end{array}$ & $\begin{array}{c}\text { Days } \\
\text { to first } \\
\text { harvest }\end{array}$ & $\begin{array}{c}\text { Yield per } \\
\text { bag }(\mathbf{g})^{*}\end{array}$ \\
\hline 1. No casing & - & $46.0^{\mathrm{a}}$ & $55.7^{\mathrm{a}}$ & $49.23^{\mathrm{c}}$ \\
2. Termite clay soil : Sand : DCM 3:1:1 & $4.1^{\mathrm{c}}$ & $39.5^{\mathrm{bc}}$ & $45.8^{\mathrm{c}}$ & $84.63^{\mathrm{a}}$ \\
3. Paddy soil : Coir dust (1:1.5) & $5.2^{\mathrm{b}}$ & $40.9^{\mathrm{b}}$ & $50.0^{\mathrm{b}}$ & $63.16^{\mathrm{b}}$ \\
4. Half burnt paddy husk : DCM (2:1) & $4.1^{\mathrm{c}}$ & $32.3^{\mathrm{d}}$ & $40.0^{\mathrm{d}}$ & $82.05^{\mathrm{a}}$ \\
5. Coir dust : Compost : DCM (1:1:1) & $6.1^{\mathrm{a}}$ & $41.4^{\mathrm{ab}}$ & $47.6^{\mathrm{bc}}$ & $62.39^{\mathrm{b}}$ \\
6. DCM : Sand : Loamy soil (1:1:1) & $4.1^{\mathrm{c}}$ & $35.7^{\mathrm{cd}}$ & $46.2^{\mathrm{c}}$ & $62.02^{\mathrm{b}}$ \\
\hline
\end{tabular}

${ }^{*}$ Within 21 days of pin head formation. Means followed by the same letter within a column are not significantly different at $p=0.05$ level. DCM-Dry cattle manure

(3497.2 g) for the entire growth period was obtained with a mixture of paddy soil and coir dust (1:1.5) next to Netherland peat moss (3721.5 g). However, the effect could be different on MK-White (Calocybe sp.) due to their variation in growth requirements. In addition, paddy soil may differ from place to place.

As depicted in Figure 2, the highest yield per bag within a 2-month period from pin head formation was given by the casing mixture of termite clay soil: sand: dry cattle manure $(3: 1: 1 ; 761.67 \mathrm{~g} / \mathrm{bag})$ followed by the casing mixture of half burnt paddy husk: dry cattle manure $(2: 1 ; 738.45 \mathrm{~g} / \mathrm{bag})$. MKWhite variety is reported to give an average yield of $600-850 \mathrm{~g} / 1 \mathrm{~kg}$ media (Anon, 2016b). The above two casing mixtures (T2 and $\mathrm{T} 4$ in Figure 1) produced mushroom yields well within this range. Absence of a casing mixture (Control 1) resulted in the lowest total yield of $413.32 \mathrm{~g} / \mathrm{bag}$. 


\section{Effect of Physico-chemical Properties of Casing Materials on Mycelium Growth and Mushroom Yield}

Optimum physico-chemical properties in a casing mixture could enhance fruiting body production of MK-White mushroom. High water holding capacity, light weight, high porosity and neutral or slightly alkaline $\mathrm{pH}$ can favour the fruiting body formation.

Low bulk densities of coir dust: compost: dry cattle manure $(1: 1: 1)$ and half burnt paddy husk: dry cattle manure $(2: 1)$ casing mixtures were associated with their high porosity (92\% and $86 \%$, respectively). Casing mixture of termite clay soil: sand: dry cattle manure (3:1:1) also had higher porosity of $79 \%$ compared to the remaining two mixtures (Table 1). Casing materials with high porosity can maintain the aerobic respiration and regulate the temperature in the growing medium. High pore space of casing materials can retain adequate moisture and thereby, tend to yield larger mushrooms. Poor air exchange capacity associated with low porosity leads to buildup of carbon dioxide level and consequently mushrooms emerge as stunted (Jarial et al., 2005). Porosity was considerably low $(47 \%)$ in the casing mixture of dry cattle manure: sand: loamy soil (1: 1: 1; Table 1) and it resulted in a lower yield per bag (62.02 g; $c f$. Tables 1 and 2).

Casing material should have a $\mathrm{pH}$ of 7.0 - 7.5 for optimum mushroom yield (Maheshwari, 2013). Acidic or alkaline casing media will stop emergence of pin heads and delay the formation of fruiting bodies. Some nutrients which affect the development of sporophores become unavailable in the presence of high acidic or alkaline conditions. The recommended $\mathrm{pH}$ to obtain an optimum yield from MK-White is $7.23-7.30$.

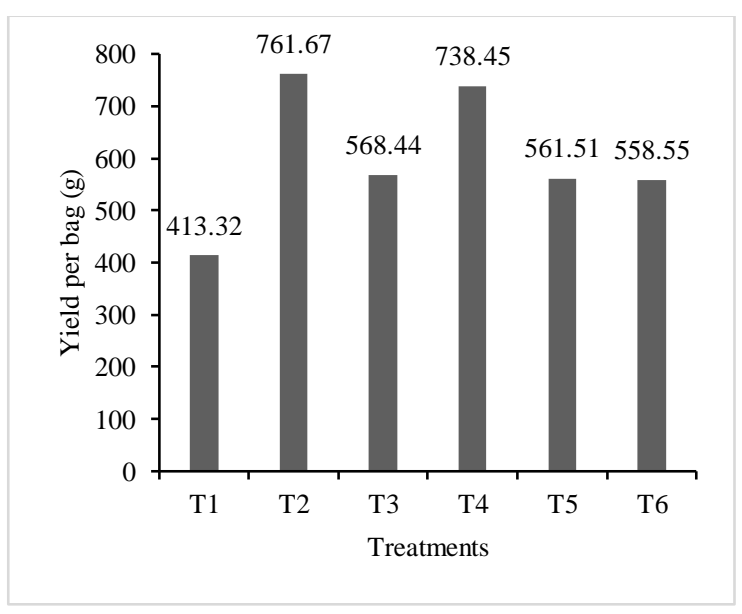

Figure 2. Yield of Makandura White mushroom within two months of pin head formation under different casing mixtures (treatments).

T1- No casing (Control 1), T2- Termite clay soil: Sand: Dry cattle manure (3:1:1; Control 2), T3Paddy soil: Coir dust (1:1.5), T4- Half burnt paddy husk: Dry cattle manure (2:1), T5- Coir dust: Compost: Dry cattle manure (1:1:1), T6- Dry cattle manure: Sand: Loamy soil $(1: 1: 1)$

The casing mixtures of termite clay soil: sand: dry cattle manure $(3: 1: 1)$ and half burnt paddy husk: dry cattle manure $(2: 1)$ had their $\mathrm{pH}$ in this desirable range.Moisture in casing material creates a specific micro climatic condition around the mushroom growing medium. High moisture in the casing provides humidity for the growth and development of fruiting bodies and reduces its temperature thereby, resulting in high yield. Emergence of pin 
heads stop due to presence of warmer conditions in a casing mixture.

The optimum moisture content of the casing mixture should be $60-65 \%$ (dry weight basis) for MK-White mushroom (Rajapakse et al., 2017). The casing mixtures of termite clay soil: sand: dry cattle manure $(3: 1: 1)$ and half burnt paddy husk: dry cattle manure $(2: 1)$ retained their moisture level in the favourable range. Therefore, the higher yields obtained with those two casing mixtures could be partially attributed to their moisture levels. The casing mixture of coir dust: compost: dry cattle manure $(1: 1: 1)$ had a high moisture content of $73 \%$ and it resulted in low yield (cf. Tables 1 and 2). Casing materials with high levels of moisture could lead to a soggy substrate and provide a medium for unwanted mold growth. In addition, it results in poor drainage and lack of aeration for the mycelium. Thus, inhibition of perspiration, renders the development of fruiting bodies impossible and results in the development of non-desired organisms such as nematodes and bacteria (Bellettini et al., 2016). On the other hand, drying out of mycelium due to low humidity results in low growth and poor yield.

Yield performance of treatment without casing was significantly low when compared to all other treatments. Fundamental requirements like stress induction, moisture, $\mathrm{pH}$ and other physicochemical conditions which are necessary for the growth and fructification processes were not obtained without casing. Mushroom cropping depends on physical, chemical and biological factors, which interact during the growing and fructification processes and achieving commercially adequate production levels depends on the balance of these factors (Rangel et al., 2006).

\section{CONCLUSION}

The casing mixture of termite clay soil: sand: dry cattle manure $(3: 1: 1)$ can be replaced with the readily available half burnt paddy husk: dry cattle manure $(2: 1)$ mixture without causing a significant decrease in yield. Moreover, the casing mixture of half burnt paddy husk: dry cattle manure (2:1) provides the required physicochemical conditions to grow MK-White mushroom. Therefore, a mixture of half burnt paddy husk: dry cattle manure $(2: 1)$ can be recommended as an appropriate casing material for MK-White mushroom production.

\section{ACKNOWLEDGEMENT}

Sincere thanks are extended to $\mathrm{Mr}$. K.H.M.I. Karunarathne, Department of Plantation Management, Wayamba University of Sri Lanka, for his assistance in statistical data analysis. Authors wish to thank all staff members of Mushroom Research Unit and Soil Division of RARDC, Department of Agriculture, Makandura.

\section{REFERENCES}

Anon, (2016a). Insight in to edible and medicinal mushroom research in Sri 
Lanka. Available from: https://www.pressreader.com/srilanka /sunday-times-sri-lanka. (Accessed 17 July 2017).

Anon (2016b). Performance Report 2015. Department of Agriculture, Peradeniya, Sri Lanka. Available from:

https://www.doa.gov.lk/HORDI/imag es/ /English2015.pdf (Accessed 17 July 2017).

Baysal, E., Yigitbasi, O.N., Colak, M., Toker, H., Simsek, H. and Yilmaz, F. (2007). Cultivation of Agaricus bisporus on some compost formulas and locally available casing materials. Part 1: Wheat straw-based compost formulas and locally available casing materials. African Journal of Biotechnology, 6(19): 2225-2230.

Bellettini, M.B., Fiorda, F.A., Maieves, H.A., Teixeira, G.L., Avila, S., Hornung, P.S., Junior, A.M. and Ribani, R.H. (2016). Factors affecting mushroom Pleurotus spp. Saudi Journal of Biological Sciences (in press).

DOI: 10.1016/j.sjbs.2016.12.005

Colak, M., Baysal, E., Simsek, H., Toker, H. and Yilmaz, F. (2007). Cultivation of Agaricus bisporus on wheat straw and waste tea leaves based composts and locally available casing materials. Part 3: Dry matter, Protein and Carbohydrate contents of Agaricus bisporus. African Journal of

Biotechnology, 6(24): 2855-2859.

Jarial, R.S., Shandilya, T.R. and Jarial, K. (2005). Casing in mushroom beds A Review. Agricultural Reviews,
26(4): 261-271.

Jayanga, K.W.S., Udayanga, R.I.G. and Jayasekara, S.J.B.A. (2016). Effect of casing mixtures on yield of button mushroom (Agaricus bisporus). In: Proceedings of $15^{\text {th }}$ Agriculture Research Symposium of the Wayamba University of Sri Lanka, Gonawila, Sri Lanka, 284-288.

Maheshwari, S. (2013). A guide for white button mushroom (Agaricus bisporus) production. Open Access Scientific Reports, 2(3): 2-3.

Rainey, P.B. (1985). A Study of Physical, Chemical and Biological Properties of the Mushroom Casing Layer, M.Sc. Thesis, University of Canterbury, New Zealand.

Rajapakse, P., Jayarathna, N.P.W., Manjula, N.V.A. and Piyathissa, D.D.E. (2017). Evaluation of new edible mushroom variety. In: Proceedings of Annual Sessions of the Department of Agriculture, Sri Lanka. Rangel, J.I., Leal, H., Palacios, M.S., Sanchez, S., Ramirez, R. and Mendeza, G. T. (2006). Coconut fiber as casing material for mushroom production. Terra Latinoamericana, 24(2): 207-213.

Subbiah, K.A. and Balan, V. (2015). A Comprehensive Review of Tropical Milky White Mushroom (Calocybe indica P \& C). Mycobiology, 43(3): 184-194. 